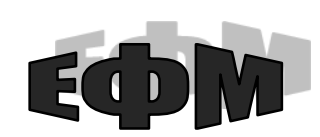

http://efm.vsau.org/

УАК 657.47:658.8

JEL Classification: M41

\section{ОБЛІКОВЕ ЗАБЕЗПЕЧЕННЯ УПРАВЛІННЯ \\ МАРКЕТИНГОВОЮ СТРАТЕГІЄЮ ПІДПРИЕМСТВА $\odot$}

Н.Л. ПРАВДЮК, доктор економічних наук, професор, завідувач кафедри бухгалтерського обліку, Вінницький національний аграрний університет (м. Вінниця)

У статті визначено місие і обтрунтовано значення маркетингової стратегії та ї̈ складових елементів у загальній ієрархії стратегій розвитку підприємства. Встановлено, щуо маркетингова стратегія визначає вибір складових елементів комплексу маркетингу, передбачаючи обтрунтування вибору та формування цільового ринку, номенклатури та асортименту продукиії, ияінової, збутової та комунікаційної політики. На основі обтрунтування важливості розробки та реалізації маркетингової стратегії підприємства в умовах сучасного бізнес-середовища досліджено структуру інформачійного забезпечення управління маркетинговою стратегією, яка включає інформащійні ресурси зовнішнього та внутрішнього середовища. Встановлено, щзо основою інформаційного забезпечення управління маркетинговою стратегією підприємства, яке генерується внутрішнім середовищем, $\epsilon$ бухгалтерський облік господарських операчій, пов'язаних із здійсненням маркетингових досліджень та заходів, щзо охоплює етапи первинного, поточного та підсумкового обліку. Для формування якісного обліково-інформачійного забезпечення управління маркетинговою стратегією підприємства узагальнено класифікаиію витрат маркетингової діяльності та порядок їх документального оформлення, а також надано пропозиції щзодо відображення облікової інформації на рахунках бухгалтерського обліку та у фінансовій звітності. Запропоновано організаційнометодичний механізм формування обліково-інформачійного забезпечення управління маркетинговою стратегією підприємства відповідно до складових комплексу маркетингу, щзо дає змогу генерувати інформаційні потоки в необхідному аналітичному розрізі відповідно до потреб та специфіки управління.

Ключові слова: маркетингова діяльність, маркетингова стратегія, управління, товарна політика, цінова політика, збутова політика, ринкова політика, комунікаційна політика, бухгалтерський облік, облікове забезпечення.

Табл.: 1. Рис.: 4. Літ.: 20.

\title{
ACCOUNTING SUPPORT OF THE MARKETING STRATEGY MANAGEMENT
} OF AN ENTERPRISE

PRAVDIUK Nataliia, Doctor of Economic Sciences, Professor, Head of the Accounting Department, Vinnytsia National Agrarian University (Vinnytsia) 
The place of the marketing strategy and its constituent elements in the general hierarchy of the enterprise development strategies is identified and their importance is substantiated. It is established that the marketing strategy determines the choice of components of the marketing complex, providing justification for the selection and formation of the target market, product range, product mix, price, marketing and communication policy. The structure of the information support of marketing strategy management at the enterprise, which includes information resources of the external and internal environment, is investigated on the base of substantiation of the importance of developing and implementing the marketing strategy of an enterprise under conditions of modern business environment. It is established that the basis of information support of the marketing strategy management at the enterprise, which is generated by the internal environment, is the accounting of business operations related to implementation of the marketing research and activities, covering the stages of primary, current and final accounting. To form a qualitative accounting and information support of the marketing strategy management at the enterprise, the classification of expenses for the marketing activity and the procedure of their documentary registration are generalized, and guidelines on the display of accounting information in the accounts and financial statements are provided. The organizational and methodical mechanism of formation of the accounting and information support of the marketing strategy management of an enterprise in accordance with the components of the marketing complex, which enables to generate information flows in necessary analytical terms according to the needs and specifics of management, is suggested.

Key words: marketing activity, marketing strategy, management, commodity policy, price policy, marketing policy, market policy, communication policy, accounting, accounting support.

Tabl.: 1. Fig.: 4. Ref.: 20.

\section{УЧЁТНОЕ ОБЕСПЕЧЕНИЕ УПРАВЛЕНИЯ МАРКЕТИНГОВОЙ СТРАТЕГИЕЙ ПРЕДПРИЯТИЯ}

управления маркетинговой стратегией предприятия, которое генерируется внутренней средой, является бухгалтерский учёт хозяйственных операциий, 


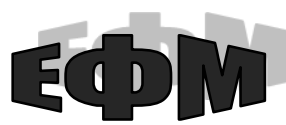

http://efm.vsau.org/

связанных с осуществлением маркетинговых исследований и мероприятий, который охватывает этапы первичного, текущего и итогового учёта. Для формирования качественного учётно-информационного обеспечения управления маркетинговой стратегией предприятия обобщена классификаџию расходов маркетинговой деятельности и порядок их документального оформления, а также подань рекомендации по отражению учётной информации на счетах бухгалтерского учёта и в финансовой отчётности. Предложен организационно-методический механизм формирования учётно-информационного обеспечения управления маркетинговой стратегией предприятия в соответствии с составляющими комплекса маркетинга, который позволяет генерировать информационные потоки в необходимом аналитическом разрезе в соответствии с потребностями и спецификой управления.

Ключевые слова: маркетинговая деятельность, маркетинговая стратегия, управление, товарная политика, ценовая политика, сбытовая политика, рыночная политика, коммуникационная политика, бухгалтерский учёт, учётное обеспечение.

Табл.: 1. Рис.: 4. Лит.: 20.

Постановка проблеми. Діяльність підприємства в умовах ринкового середовища, що супроводжується посиленням конкурентного протистояння за ринки збуту продукції, потребує ефективного управління його маркетинговою стратегією, яка покликана забезпечити обгрунтування цілей і завдань суб' єктів господарювання на кожному окремому ринку (сегменті ринку) і стосовно кожного виду продукції 3 урахуванням особливостей бізнес-середовища, цінової політики та споживчого попиту. Водночас розробка та реалізація маркетингової стратегії підприємства мають базуватися на достовірній, повній та своєчасній інформації про кон'юнктуру ринку, його насиченість та місткість, кількість конкурентів, тип ринкової структури або моделі ринку, тобто на тій інформації, яка дає змогу підприємству отримати чіткі відповіді на фундаментальні питання економіки: що, як і для кого виробляти? При цьому значна частина інформаційного забезпечення управління маркетинговою стратегією має генеруватися обліковою системою підприємства. Враховуючи зазначене, теоретичним, організаційно-методичним та практичним аспектам ведення бухгалтерського обліку в контексті задоволення інформаційних потреб стратегічного маркетингу необхідно приділяти належну увагу.

Аналіз останніх досліджень та публікацій. Питання щодо розкриття сутності маркетингової стратегії, специфіки їі розробки та класифікації, а також формування облікового забезпечення як основи інформаційного забезпечення управління маркетинговою діяльністю підприємства, знайшли висвітлення у працях багатьох вчених-економістів. Так Д. Мельник [1] досліджено особливості формування маркетингової стратегії підприємства в сучасних умовах ведення бізнесу, визначено іiі місце та значення в загальній ієрархії стратегій розвитку підприємства. С. Семенюк [2] запропоновано алгоритм вибору оптимальної маркетингової стратегії, що включає оцінювання поточної стратегії фірми, аналіз портфеля бізнесу та виявлення альтернативних маркетингових стратегій.

А. Савчук [3] висвітлено основні засади формування інформаційного забезпечення управління маркетинговою стратегією підприємства, визначено основні складові системи інформаційного забезпечення стратегічного маркетингу підприємства, відводячи при цьому обліковій та аналітичній системам підприємства домінуючу роль. Проблему формування інформаційного забезпечення управління 
витратами на маркетингову діяльність підприємств досліджено у працях С. Вітер і 3. Вітер [4]. Зокрема, авторами обгрунтовано відмінність маркетингових витрат i витрат на збут, запропоновано перелік витрат на маркетинг на підставі функціонального підходу до їх управління та порядок відображення маркетингових витрат в системі бухгалтерських рахунків.

Теоретичні та практичні аспекти обліку і аналізу витрат маркетингової діяльності підприємства висвітлено у працях В. Дерія [5]. Автором, зокрема, запропоновано для обліку витрат на збут у складі синтетичного рахунку 93 «Витрати на збут» відкривати субрахунки у відповідності до переліку витрат на збут, наведених у п. 19 П(С)БО 16 «Витрати». Такий підхід, на думку вченого-обліковця, сприятиме формуванню деталізованої аналітичної інформації про витрати на збут продукції, як інформаційної бази оперативного, тактичного і стратегічного аналізу ефективності маркетингової діяльності компанії.

Проблемі класифікації витрат на маркетингову діяльність підприємства присвячені наукові доробки К. Назарової та В. Мисюк [6], у яких авторами обгрунтовано економічну сутність поняття «витрати на маркетинг», наведено класифікацію витрат на збут продукції та пропозиції щодо відображення їх в обліковій системі підприємства. Крім того, науковцями висунута гіпотеза про неможливість існуючої системи бухгалтерського обліку забезпечувати потреби користувачів облікових даних в оперативній та якісній інформації про маркетингову діяльність підприємства.

I. Поліщук [7] запропоновано здійснювати аналіз маркетингової діяльності шляхом визначення оптимального співвідношення між основними показниками фінансово-господарської діяльності підприємства, зокрема фінансовим результатом до оподаткування, чистим доходом, валютою балансу та витратами на збут. Крім того, автором для цілей бухгалтерського обліку рекомендовано класифікувати витрати на збут підприємства на такі групи: основні витрати (витрати, пов'язані зі збутом продукції - витрати на оплату праці персоналу, що забезпечують збут, витрати на оренду та утримання необоротних активів, що забезпечують збут продукції, витрати інших матеріальних цінностей тощо); допоміжні витрати витрати, пов'язані з уточненням маркетингової товарної та цінової політики щодо наявного асортименту, витрати на маркетингові дослідження та рекламу, витрати на відрядження працівників, зайнятих збутом продукції; витрати на розвиток маркетингової товарної та цінової політики щодо оновлення асортименту.

Грунтовні дослідження, спрямовані на обгрунтування теоретичних, організаційних і методичних положень та розробку практичних рекомендацій щодо вдосконалення обліку і аналізу витрат маркетингової діяльності, висвітлено у працях О. Лукан [8; 9]. Зокрема, автор надає пропозиції щодо удосконалення класифікації та документального забезпечення обліку витрат маркетингової діяльності, методики відображення маркетингових витрат у системі рахунків бухгалтерського обліку та звітності підприємства.

Дослідження, спрямовані на визначення сутності маркетингової стратегії та специфіки іiі розробки на мікро-, мезо- та макрорівнях, вирішення багатоаспектної проблеми формування достовірного обліково-аналітичного забезпечення управління маркетинговою діяльністю, зокрема щодо обліку та аналізу витрат на маркетингову діяльність, нормативно-правового регламентування обліку маркетингової діяльності, 


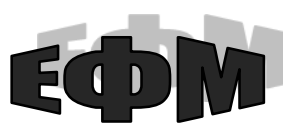

http://efm.vsau.org/

а також методики відображення інформації про маркетингову діяльність у системі бухгалтерських рахунків та фінансовій звітності, знайшли відображення у працях В. Бондаренка [10], Н. Гудзенко, Н. Коваль, Т. Плахтій [11], Г. Калетніка [12], Н. Правдюк [13], І. Ліганенка [14], О. Пальчук, В. Савченко, Н. Тошиної [15] та інших науковців.

Однак, незважаючи на значні напрацювання вчених-економістів в частині обгрунтування теоретичних та практичних положень формування обліковоінформаційного забезпечення системи стратегічного маркетингу компанії, організаційні та методичні аспекти ведення бухгалтерського обліку в контексті задоволення інформаційних потреб управління маркетинговою стратегією підприємства залишаються невирішеними через складність та багатогранність проблемних питань.

Формулювання цілей статті. Метою статті $\epsilon$ обгрунтування та розробка організаційно-економічного механізму формування облікового забезпечення управління маркетинговою стратегією підприємства.

Виклад основного матеріалу дослідження. Сучасні умови ведення бізнесу характеризуються динамічністю та мінливістю політичної і соціально-економічної ситуації, тому підприємства вимушені діяти в умовах підвищеного ризику та невизначеності. За таких умов важливого значення набуває розробка стратегії, яка має спрямовуватись на досягнення визначених цільових параметрів діяльності господарюючих суб' єктів з урахуванням потенційного впливу чинників зовнішнього та внутрішнього характеру.

На існування невизначеності та ризиків при здійсненні виробничогосподарської діяльності вітчизняних підприємств вказують статистичні дані. Так, за даними Державної служби статистики України, фінансові результати підприємств протягом 2010-2017 рр. мали нестійку динаміку, що стало наслідком складної політико-економічної ситуації. Якщо в 2010 р. сукупний результат операційної діяльності українських підприємств становив 100799,5 млн грн, то у 2014 р. вітчизняні підприємства отримали збиток від операційної діяльності, що становив 133698,7 млн грн. Проте уже в 2017 р. величина операційного прибутку становила 439488,1 млн грн, що майже у 4,5 разів більше у порівнянні з базовим роком. Рентабельність операційної діяльності протягом аналізованого періоду коливалася в межах від $-4,1$ до $+8,8 \%$. Найменшого значення $(-4,4 \%)$ рентабельність операційної діяльності становила у 2014 р., що стало наслідком отриманням вітчизняними підприємствами збитку за результатами операційної діяльності (рис. 1).

Наявність таких диспропорцій у діяльності вітчизняних підприємств стало результатом дії негативних чинників зовнішнього та внутрішнього характеру, що призвели до втрати суб' єктами господарювання цільових ринків збуту продукції, розриву сталих господарських зв'язків з постачальниками сировини та матеріалів, зниження споживчого попиту та інших негативних наслідків. Діяльність підприємств сьогодні здійснюється в умовах нестабільного середовища, тому для мінімізації таких ризиків підприємствам необхідно розробляти стратегії розвитку, від реалізації яких залежатиме здатність підприємств адекватно реагувати на виклики сучасного буття та досягати цільових показників діяльності. 


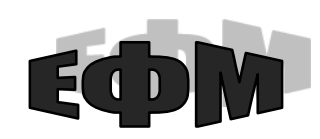

http://efm.vsau.org/

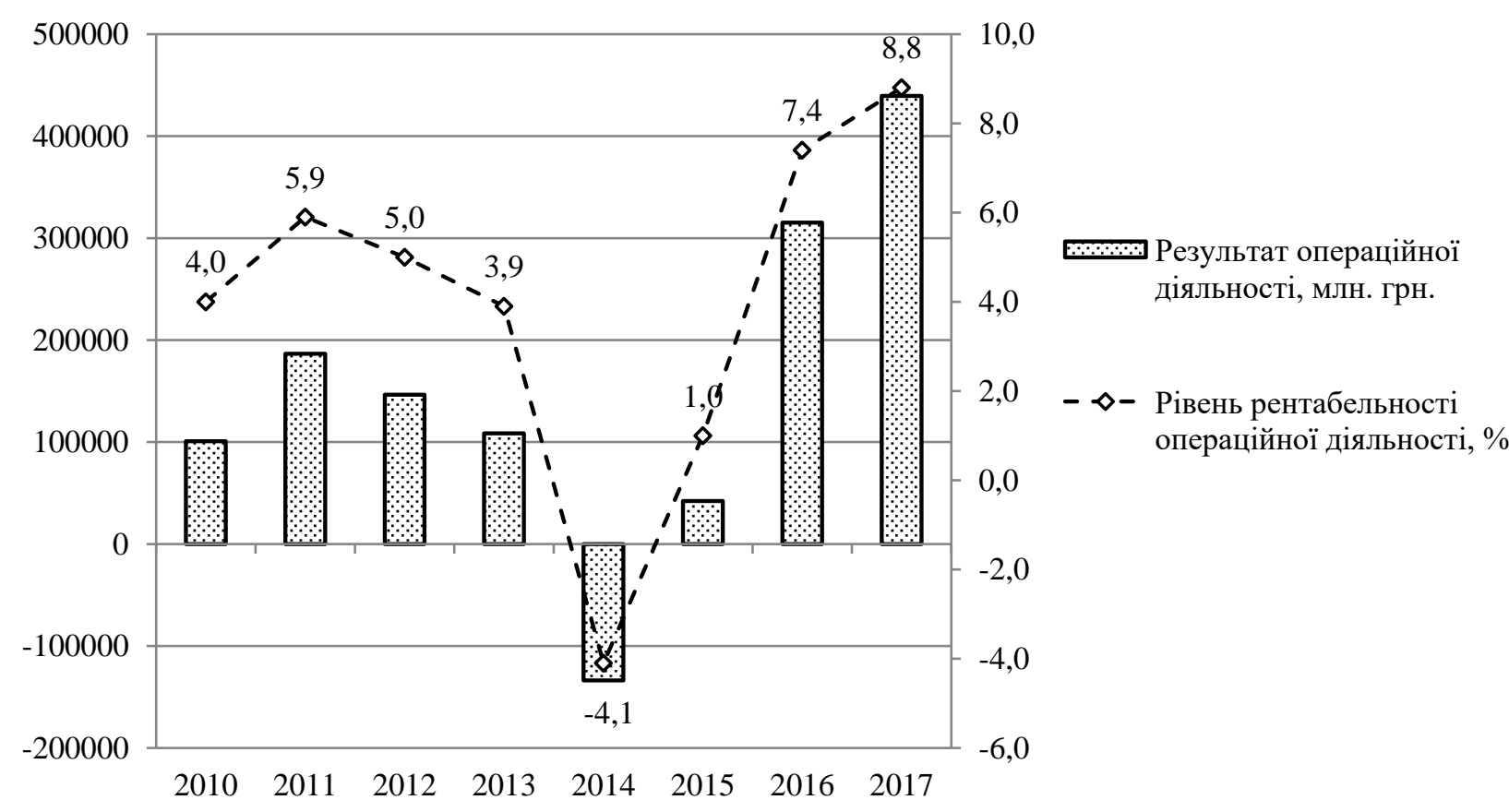

Рис. 1. Динаміка результатів операційної діяльності та рентабельності
вітчизняних підприємств у 2010-2017 pp.
Джерело: сформовано автором за даними Державної служби статистики Украйни

Суть стратегії полягає у визначенні конкурентного вибору, який дозволяє підприємству не тільки використовувати поточні можливості, що виникли, а концентрувати ресурси для вирішення пріоритетних завдань, що забезпечують переваги у суворо визначених та перспективно вигідних напрямах. Тому розробка та вибір певної стратегії для ії втілення у життя $є$ надзвичайно важливим питанням, від якого може залежати не тільки успішна діяльність, а й взагалі існування підприємства $[1$, c. 214$]$.

Розробка стратегій підприємства $є$ результатом стратегічного планування. Відповідно до визначених цілей та напрямів діяльності підприємства виділяють ділові стратегії (корпоративна стратегія, стратегія розвитку та конкурентна стратегія тощо) та функціональні стратегії (маркетингова, виробнича, фінансова, інвестиційна, стратегія НДДКР тощо). При цьому провідний фахівець Гарвардської школи бізнесу Д. Хансен зазначає, що $80 \%$ стратегій підприємства припадає на частку саме маркетингової стратегії [2, с. 206]. Це зумовлено ринковими умовами ведення бізнесу, коли для більшості підприємств вирішення важливих питань знаходиться у площині маркетингу. Саме оптимальність розробленої маркетингової стратегії визначає здатність підприємства успішно освоювати нові ринки збуту продукції, залишатися конкурентоспроможним та фінансово стійким в динамічному, часто нестабільному політичному та соціально-економічному середовищі, що, зрештою, корелюється із здатністю підприємства досягати цільових параметрів своєї діяльності на кожному окремому ринку збуту продукції.

Відповідно до економічної літератури під маркетинговою стратегією необхідно розглядати систему організаційно-технічних і фінансових заходів щодо інтенсифікації виробництва, реалізації продукції, підвищення іiі конкуренто- 
спроможності, активного впливу на попит та пропозицію. Маркетингова стратегія втілюється в програмі заходів щодо вдосконалення виробництва та реалізації продукції для забезпечення високих і стійких прибутків [16, с. 256].

Маркетингова стратегія займає центральне місце в системі бізнес-планування підприємства, визначає вибір складових елементів комплексу маркетингу, передбачаючи обгрунтування вибору та формування цільового ринку, номенклатури та асортименту продукції, цінової, збутової та комунікаційної політики (рис. 2).

Ключове значення в системі стратегічного планування діяльності підприємства займає інформаційне забезпечення, від якості, достовірності та повноти якого залежить ефективність розробленої маркетингової стратегії, здатність господарюючого суб'єкта приймати раціональні управлінські рішення в умовах невизначеності та ризику. Під інформаційним забезпеченням в наведеному контексті необхідно розглядати систему, завдяки функціонуванню якої забезпечується задоволення інформаційних потреб керівників підприємства в процесі прийняття стратегічних маркетингових рішень.

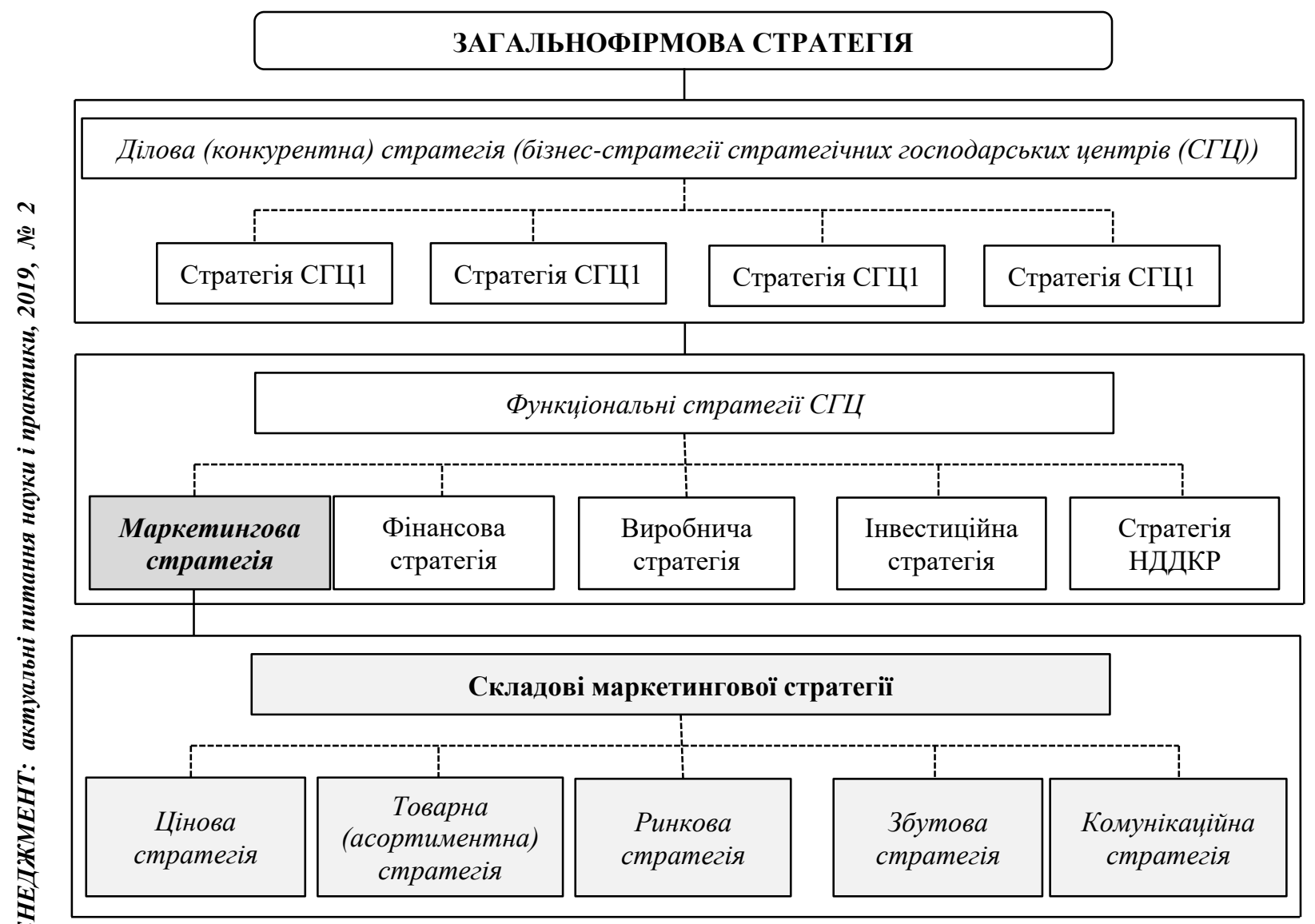

\section{Рис. 2. Місце маркетингової стратегії та її складові елементи в ісрархії стратегій підприсмства \\ Джерело: сформовано автором з використанням [1]}

Джерелом отримання інформації для потреб стратегічного маркетингу $є$ зовнішнє та внутрішнє середовище діяльності підприємства. До зовнішньої інформації відносять відомості щодо маркетингового середовища функціонування підприємства (інформація про насиченість та місткість цільових ринків, конкурентів, 
постачальників, рівень цін, споживчий попит, кон'юнктуру ринку праці тощо) та дані маркетингових досліджень, спрямованих на емпіричне, теоретичне та практичне вивчення і аналіз маркетингового середовища, в якому діє підприємство. Втім, зовнішня інформація, через складність ऑї отримання та опрацювання в контексті задоволення потреб стратегічного маркетингу, виконує допоміжну роль.

Виходячи 3 вищесказаного, можна стверджувати, що основним джерелом формування інформаційного забезпечення стратегічного маркетингу є внутрішнє середовище діяльності підприємства, центральне місце в якому відводиться бухгалтерському обліку та фінансовій звітності. За оцінками вчених-економістів частка облікової інформації в структурі інформаційного забезпечення управління маркетинговою стратегією підприємства становить 88-90\% [3, с. 67]. Це вказує на необхідність створення дієвої системи інформаційного забезпечення управління маркетинговою стратегією з чітким акцентом на вивченні механізму обробки та порядку узагальнення даних бухгалтерського обліку підприємства, що дасть змогу мінімізувати невизначеність та ризики при прийнятті маркетингових рішень (рис. 3).

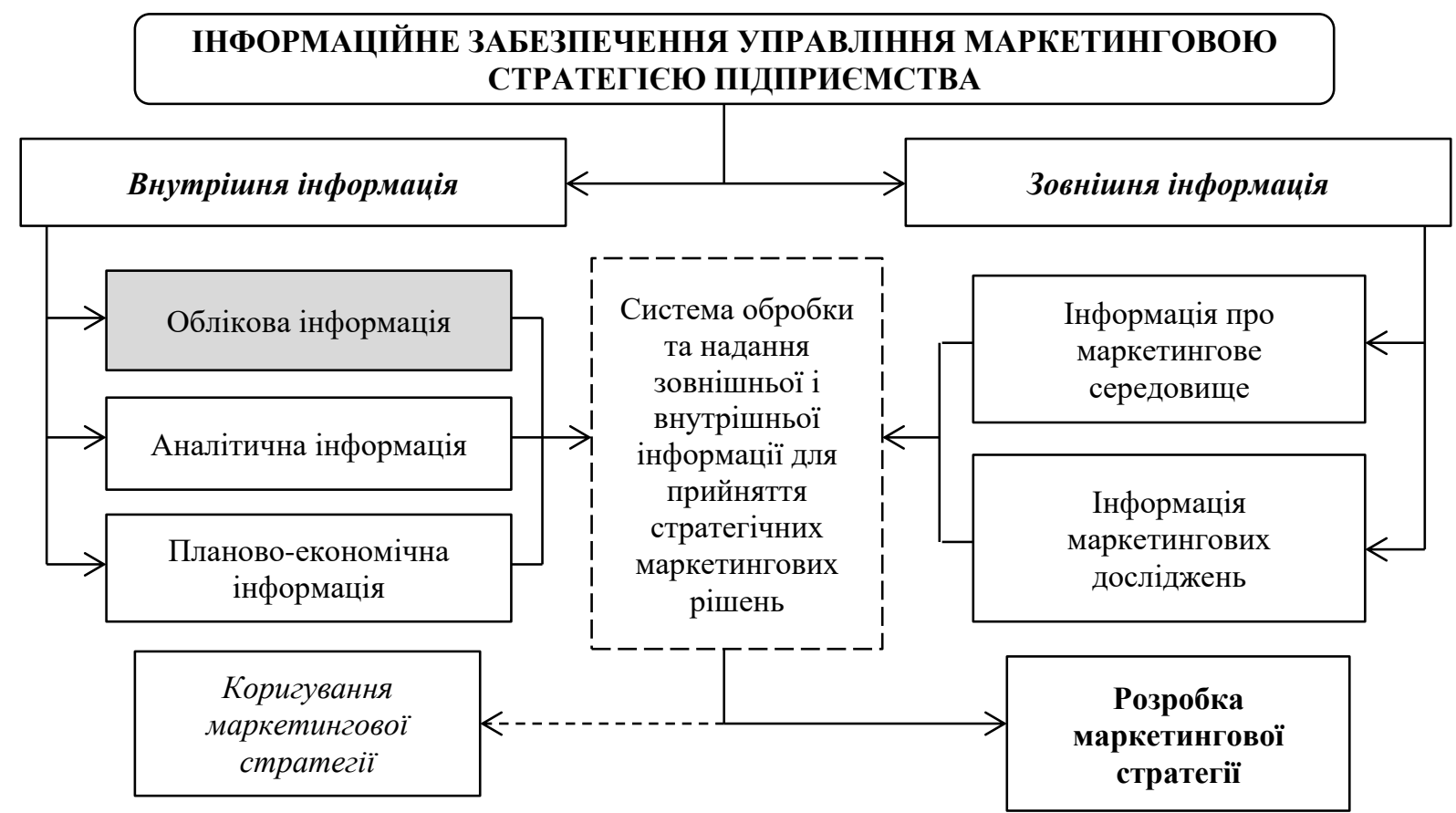

\section{Рuc. 3. Система інформаційного забезпечення управління маркетинговою стратегісю підприсмства}

Джерело: сформовано автором

Враховуючи вищезазначене, розглянемо організаційно-методичні аспекти відображення та узагальнення в обліковій системі підприємства інформації про його маркетингову діяльність в контексті реалізації маркетингових заходів, спрямованих на обгрунтування вибору та формування номенклатури і асортименту продукції, цільового ринку, цінової, збутової та комунікаційної політики.

Маркетингова діяльність підприємства, як і будь-який інший вид діяльності, тягне за собою певні витрати, які мають бути економічно доцільними, фінансово обгрунтованими та в повному обсязі відображеними в обліковій системі. Однак усталена практика ведення бухгалтерського обліку на вітчизняних підприємствах унеможливлює акумулювання відомостей про проведені маркетингові заходи та пов'язані 3 ними 
витрати, що не дозволяє повною мірою задовольнити інформаційні запити зовнішніх і внутрішніх користувачів. Виходячи з цього, розглянемо детально порядок відображення та узагальнення інформації про витрати маркетингової діяльності підприємства за етапами облікового процесу та оцінимо рівень інформаційної місткості фінансової звітності на предмет представлення у ній даних про витрати, що виникають у процесі розробки та реалізації маркетингової стратегії підприємства.

Обліковий процес розпочинається з документування господарських операцій, які здійснюються підприємством у процесі розробки та реалізації стратегій маркетингу. До таких господарських операцій необхідно відносити дії або події, які призводять до змін в структурі активів, зобов'язань і власного капіталу та пов'язані із здійсненням маркетингової діяльності, зокрема, це господарські операції, що пов'язані з реалізацією товарної (асортиментної), ринкової, збутової, цінової та комунікаційної стратегій.

Документування господарських операцій, пов'язаних 3 управлінням маркетинговою стратегією, передбачає фіксування на первинних або машинних носіях відомостей про понесені витрати підприємства на проведення різних маркетингових заходів, зокрема:

1) на розробку та реалізацію товарної стратегії: витрати на проведення маркетингових досліджень - розробку та покращення дизайну продукції, поліпшення якості та споживчих властивостей продукції, оптимізацію наявного асортименту та створення нових видів продукції, продовження життєвого циклу продукції тощо;

2) на розробку та реалізацію збутової стратегії: витрати на складування продукції, витрати на транспортування готової продукції, витрати пакувальних матеріалів, оплата праці працівникам відділу збуту (менеджерам 3 продажу, консультантам, торговим агентам, водіям та ін.), витрати на гарантійний ремонт, витрати на утримання основних засобів та інших матеріальних необоротних активів, пов'язаних із збутом продукції тощо;

3) розробку та реалізацію цінової стратегії: витрати на проведення маркетингових досліджень - аналіз цінової політики конкурентів, споживчих цін, кон'юнктури ринку, ціноутворення, відображення витрат матеріальних, трудових і фінансових ресурсів на проведення маркетингових досліджень тощо;

4) розробку та реалізацію ринкової стратегії: витрати на проведення маркетингових досліджень - вибір сегменту ринку шляхом аналізу місткості та насиченості ринку, співвідношення попиту та пропозиції, аналіз конкурентного середовища, оплата інформаційно-консультаційних послуг тощо;

5) розробку та реалізацію комунікаційної стратегії: витрати на замовлення рекламних послуг та матеріалів (листівки, брошури та ін.), розміщення реклами у засобах масової інформації, витрати на виготовлення зовнішньої реклами (реклама у транспорті, вивіски, білборди), витрати на створення та обслуговування інтернетсайту підприємства, витрати на участь у виставках, ярмарках i дегустаціях, представницькі витрати тощо.

Усі витрати, що виникають при здійсненні маркетингової діяльності підприємства є різними за своїм економічним змістом (матеріальні витрати, витрати на оплату праці, витрати на соціальні заходи, амортизація та інші операційні витрати), тому для їх документальної фіксації використовують різні форми 


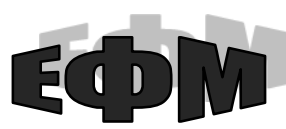

http://efm.vsau.org/

первинних документів, затверджених законодавством (документи 3 обліку матеріальних цінностей, документи з обліку грошових та розрахункових операцій, документи 3 обліку заробітної плати тощо), та документів, що складаються підприємствами самостійно (довідки та розрахунки бухгалтерії).

Для забезпечення повноти та оперативності узагальнення інформації про маркетингову діяльність підприємства в системі рахунків бухгалтерського обліку та фінансовій звітності документування має проводитись під час здійснення господарської операції, а якщо це неможливо - безпосередньо після ії проведення [17].

Після документального оформлення інформація про господарські операції підлягає узагальненню на рахунках бухгалтерського обліку. Відповідно до П(С)БО 16 «Витрати» [18] та Плану рахунків активів, капіталу, зобов’язань і господарських операцій підприємств і організацій [19], витрати маркетингової діяльності відносяться до витрат періоду, не включаються до складу виробничої собівартості та собівартості реалізованої продукції і обліковуються на синтетичному рахунку 93 «Витрати на збут».

Враховуючи те, що сучасні підприємства поряд з витратами на збут можуть нести й інші витрати, пов'язані із проведенням різного роду маркетингових досліджень і заходів, тобто витрати, які за своїм економічним змістом виходять за межі поняття «витрати на збут», рахунок 93 доцільно перейменувати на «Витрати маркетингової діяльності». Для уможливлення групування інформації за напрямами маркетингової діяльності підприємства до синтетичного рахунку 93 необхідно відкрити такі субрахунки:

- 93.1 «Витрати на реалізацію товарної політики» (аналітичний рахунок «Витрати на розробку та реалізацію товарної стратегії»);

- 93.2 «Витрати на реалізацію збутової політики» (аналітичний рахунок «Витрати на розробку та реалізацію збутової стратегії»);

- 93.3 «Витрати на реалізацію цінової політики» (аналітичний рахунок «Витрати на розробку та реалізацію цінової стратегії»);

- 93.4 «Витрати на реалізацію ринкової політики» (аналітичний рахунок «Витрати на розробку та реалізацію ринкової стратегії»);

- 93.5 «Витрати на реалізацію комунікаційної політики» (аналітичний рахунок «Витрати на розробку та реалізацію комунікаційної стратегії»).

До наведених вище субрахунків необхідно відкривати аналітичні рахунки, що дасть змогу акумулювати інформацію про понесені витрати на розробку та реалізацію відповідно товарної, збутової, цінової, ринкової та комунікаційної стратегіï.

Витрати маркетингової діяльності за своїм змістом $є$ невиробничими витратами, тому включати їх до складу виробничої собівартості та собівартості реалізованої продукції (робіт, послуг), як це пропонують робити вчені-економісти [15, с. 206-208; 9, с. 9-10], на наш погляд, є помилковим. Витрати маркетингової діяльності необхідно відносити до складу операційних витрат та наприкінці звітного періоду списувати їх для визначення фінансових результатів діяльності та враховувати при розрахунку повної собівартості продукції. Втім, погоджуємось 3 науковцями [4, с. 37], які стверджують, що віднесення усієї суми маркетингових витрат на фінансовий результат призведе до штучного заниження собівартості готової продукції і результатів збутової діяльності. 3 огляду на це, контроль за рахунком 93 «Витрати маркетингової діяльності» необхідно здійснювати 3 
особливою уважністю, адже обсяг цих витрат впливатиме на формування реалізаційної ціни та визначення рівня рентабельності (прибутковості) підприємства, що враховується при прийнятті маркетингових рішень.

Крім того, важливим аспектом облікової політики підприємства в частині бухгалтерського відображення витрат маркетингової діяльності є правильний їх розподіл між звітними періодами 3 метою достовірного визначення фінансових результатів. Це пов'язано з тим, що частина маркетингових витрат є стратегічно спрямованими, мають довгостроковий характер, тобто такі витрати безпосередньо не пов'язані у часі 3 отриманим доходом. Насамперед, це стосується витрат на реалізацію комунікаційної політики (стратегіï) підприємства (витрати на здійснення великих рекламних кампаній, витрати на розміщення зовнішньої реклами, представницькі витрати та ін.).

Таким чином, витрати на реалізацію товарної, збутової, цінової та ринкової політики (стратегіi) передують або збігаються в часі з одержанням доходу, тоді як витрати на реалізацію комунікаційної політики (стратегії) випереджають отримання доходу. Тому витрати на реалізацію комунікаційної політики (стратегії) доцільно обліковувати на рахунку 39 «Витрати майбутніх періодів» 3 поступовим щомісячним включенням цих витрат до складу відповідного субрахунку обліку витрат маркетингової діяльності. Усі інші витрати маркетингової діяльності (витрати, пов'язані з реалізацією товарної, цінової, ринкової та збутової політики (стратегіï), доцільно визнавати витратами періоду в момент їх виникнення та списувати на фінансовий результат наприкінці звітного періоду (рис. 4). Рахунки активів $i$
зобов 'язань
Рахунки 931, 932, 933, 934
791 «Результат операційної діяльності»
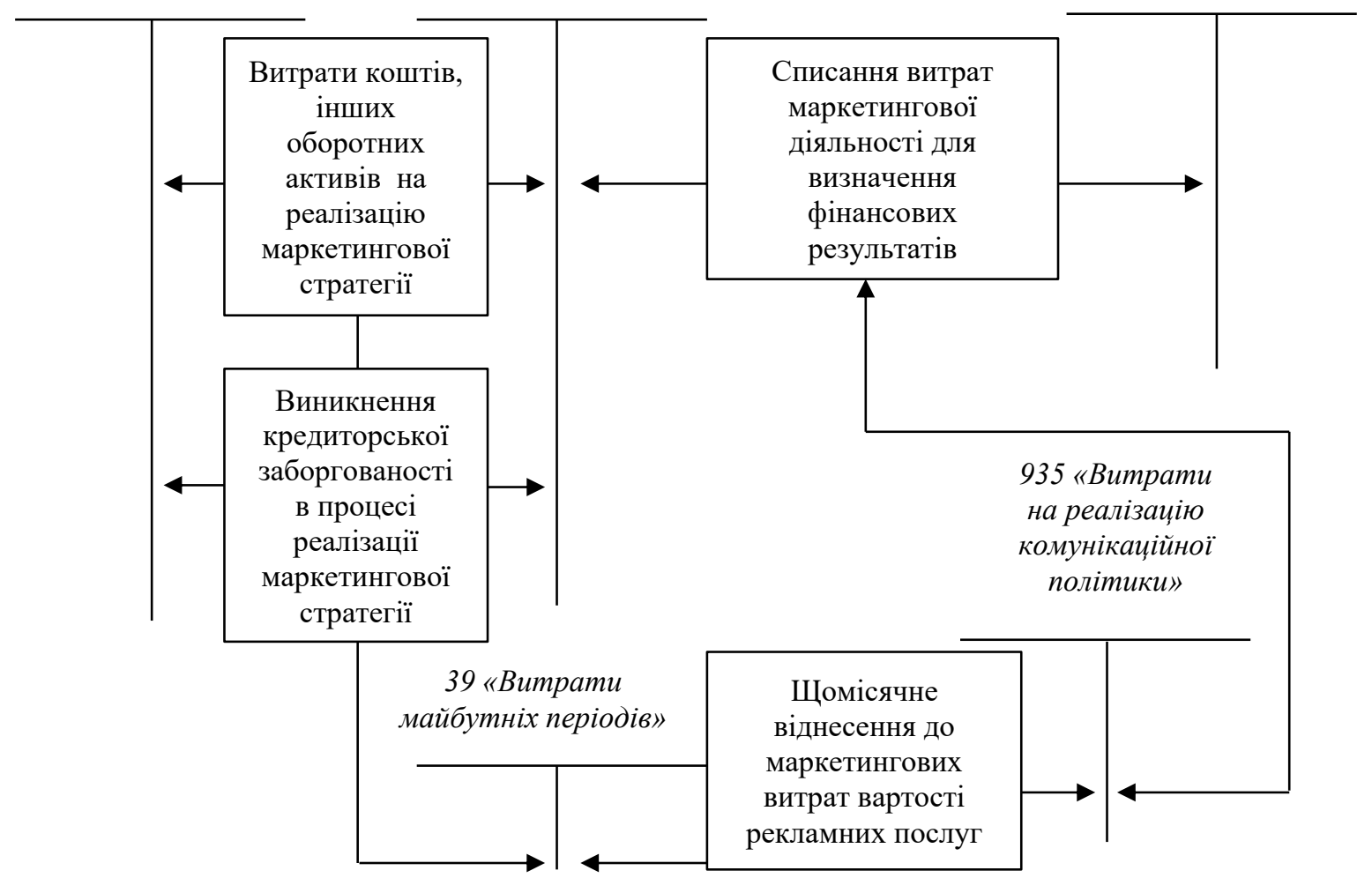

Рис. 4. Порядок відображення витрат маркетингової діяльності (маркетингової стратегіi) в системі бухгалтерських рахунків підприсмства

Джерело: сформовано автором 
Для забезпечення цілісності облікових даних подальші зусилля слід спрямувати на систематизацію даних у фінансовій звітності підприємства як важливого компоненту обліково-інформаційного забезпечення управління маркетинговою стратегією, адже саме у звітності мають подаватися узагальнені відомості про витрати підприємства на реалізацію різних маркетингових заходів та проведення досліджень. Так на сьогодні, відповідно до чинного законодавства, що регламентує порядок ведення бухгалтерського обліку та складання фінансової звітності, інформація про витрати маркетингової діяльності у звітності не подається, а наводяться відомості про понесені витрати на збут, які за своїм функціональним змістом та роллю в господарському процесі $є$ відмінними від маркетингових витрат. Витрати на збут необхідно розглядати як складовий елемент витрат маркетингової діяльності, а не навпаки, як це передбачено п. 19 П(С)БО 16 «Витрати» [18].

Відповідно до НП(С)БО 1 «Загальні вимоги до фінансової звітності» [20], інформація про понесені витрати на збут продукції знаходить відображення у формі № 2 «Звіт про фінансовий результат (Звіт про сукупний дохід)» (ряд. 2150 «Витрати на збут»). 3 урахуванням уточнення назви рахунку 93 та підходу до розуміння сутності витрат на збут і маркетингових витрат, пропонуємо перейменувати рядок 2150 на «Витрати маркетингової діяльності», що дасть змогу виокремити у звітності витрати, понесені підприємством на реалізацію маркетингових заходів (табл. 1).

Таблиияя 1

Подання інформації про витрати маркетингової діяльності у фінансовій звітності підприємства

\begin{tabular}{|c|c|c|c|c|c|}
\hline \multicolumn{3}{|c|}{ ЧИННА МЕТОДИКА } & \multicolumn{3}{|c|}{ ПРОПОЗИЦЇ АВТОРА } \\
\hline $\begin{array}{l}\text { Рахунок } \\
\text { обліку }\end{array}$ & $\begin{array}{c}\text { Код } \\
\text { рядка }\end{array}$ & $\begin{array}{l}\text { Назва } \\
\text { рядка }\end{array}$ & $\begin{array}{l}\text { Рахунок } \\
\text { обліку }\end{array}$ & Код рядка & Назва рядка \\
\hline \multicolumn{6}{|c|}{$\begin{array}{c}\text { Форма № } 2 \text { «Звіт про фінансові результати } \\
\text { (Звіт про сукупний дохід)» }\end{array}$} \\
\hline 93 & 2150 & $\begin{array}{l}\text { Витрати } \\
\text { на збут }\end{array}$ & $\begin{array}{c}93 \\
\text { (субрахунки } \\
\text { 931-935) }\end{array}$ & 2150 & $\begin{array}{l}\text { Витрати маркетинговоі } \\
\text { діяльності }\end{array}$ \\
\hline \multicolumn{6}{|c|}{$\begin{array}{c}\text { Форма № } 5 \text { «Примітки до річної фінансової звітності» } \\
\text { Розділ } V . \text { Доходи і витрати } \\
\end{array}$} \\
\hline- & - & - & \multicolumn{3}{|c|}{ Д. Витрати маркетингової діяльності } \\
\hline- & - & - & 931 & 640 & $\begin{array}{l}\text { Витрати на реалізачію } \\
\text { товарної політики }\end{array}$ \\
\hline- & - & - & 932 & 650 & $\begin{array}{l}\text { Витрати на реалізаиію } \\
\text { збутової політики }\end{array}$ \\
\hline- & - & - & 933 & 660 & $\begin{array}{l}\text { Витрати на реалізаціюо } \\
\text { цінової політики }\end{array}$ \\
\hline- & - & - & 934 & 670 & $\begin{array}{l}\text { Витрати на реалізачію } \\
\text { ринкової політики }\end{array}$ \\
\hline- & - & - & 935 & 680 & $\begin{array}{l}\text { Витрати на реалізачію } \\
\text { комунікачійної політики }\end{array}$ \\
\hline
\end{tabular}

Джерело: сформовано автором

Інформація, що наводиться у формі № 2 «Звіт про фінансовий результат (Звіт про сукупний дохід)», подається в загальному вигляді. Для представлення детальної інформації про структуру витрат маркетингової діяльності підприємства пропонуємо 


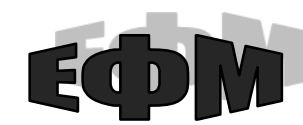

http://efm.vsau.org/

подавати детальну інформацію про витрати на проведення рекламних кампаній та інших маркетингових заходів у формі № 5 «Примітки до річної фінансової звітності» (розділ V «Доходи і витрати», ряд. 640-680).

Наведення у звітності такої інформації дасть змогу проаналізувати динаміку зміни маркетингових витрат підприємства, структуру окремих груп витрат у загальній величині витрат маркетингової діяльності та оцінити ефективність і економічність реалізації маркетингової стратегії господарюючим суб'єктом, рівень досягнення цільовим параметрів діяльності.

Таким чином, формування облікового забезпечення управління маркетинговою стратегією підприємства необхідно розглядати як сукупність інформаційних потоків про маркетингову діяльність підприємства, що генеруються його обліковою системою та спрямовуються на задоволення інформаційних потреб менеджменту в процесі розробки, обгрунтування та прийняття маркетингових рішень. Виходячи з вищенаведеної інформації представимо порядок формування облікового забезпечення в контексті управління маркетинговою стратегією підприємства як цілісний механізм, що передбачає групування облікової інформації про господарські операції, які пов'язані із здійсненням маркетингової діяльності, на різних рівнях облікового процесу - первинному, поточному та підсумковому етапах.

Висновки. У сучасних умовах ведення бізнесу, що супроводжуються зростанням невизначеності та ризику, розробка маркетингової стратегії є однією із важливих передумов успішного ведення господарської діяльності та мінімізації ризиків зовнішнього і внутрішнього середовища, оскільки дає усвідомлення того, як дослідити ринкові можливості підприємства, як провести відбір цільових ринків, як сформувати ефективну цінову та збутову політику, як розробити ефективний комплекс маркетингу й успішно втілювати маркетингові заходити в практичну діяльність. Втім, для того, щоб маркетингова стратегія відображала реальні можливості підприємства щодо досягнення заданих цільових параметрів діяльності, iii розробка та реалізація має корелюватись 3 повним, достовірним і своєчасним інформаційним забезпеченням, основу якого формує облікова система підприємства.

Відповідно до інформаційних потреб системи управління маркетинговою стратегією підприємства нами запропоновано механізм формування облікового забезпечення, який охоплює первинний, поточний та підсумковий облік. Передумовою формування якісного облікового забезпечення $\epsilon$ проведення класифікації та документування витрат маркетингової діяльності в розрізі складових маркетингової стратегії, дослідження порядку відображення інформації про маркетингові витрати в системі рахунків бухгалтерського обліку та формах фінансової звітності. Лише комплексно підійшовши до вирішення цих завдань, можна сформувати цілісну систему обліково-інформаційного забезпечення, яке задовольнятиме різнопланові інформаційні потреби користувачів облікових даних в процесі управління маркетинговою стратегією підприємства.

\section{Список використаних джерел}

1. Мельник Д.П. Маркетингова стратегія підприємства. Вісник Хмельницького національного університету. 2009. № 3. Т. 1. С. 213-219.

2. Семенюк С. Необхідність розроблення маркетингової стратегії для підприємств. Галицький економічний вісник. 2015. № 2 (49). С. 204-212.

3. Савчук А.М. Складові інформаційного забезпечення стратегічного маркетингу підприємств торгівлі. Формування ринкових відносин в Україні. 2014. № 7 (158). C. 66-71. 
4. Вітер С.А., Вітер З.Д. Обліково-аналітичне забезпечення управління маркетинговими витратами сільськогосподарських підприємств. Агросвіт. 2016. № 12. С. 34-40.

5. Дерій В.А. Витрати на збут у системі обліку й аналізу невиробничих витрат. Облік і фінанси. 2013. № 4 (62). С. 20-23.

6. Назарова К., Мисюк В. Облік витрат на маркетингові комунікації підприємства. Вісник КНТЕУ. 2017. № 5. С. 129-140.

7. Поліщук I.P. Управління витратами на збут відповідно до маркетингової стратегії підприємства: статистична оцінка та облікове забезпечення. Глобальні та національні проблеми економіки. 2016. Вип. 9. С. 832-836.

8. Лукан О.М. Документування обліку витрат маркетингової діяльності. Науковий вісник Чернівецького університету. 2015. Вип. 750. С. 125-129.

9. Лукан О.М. Облік і аналіз витрат маркетингової діяльності: автореферат дис. ... канд. екон. наук: 08.00.09.Житомир, 2017. 20 с.

10. Бондаренко В.М. Маркетингова стратегія як складова стратегії розвитку регіону. Економіка. Фінанси. Менеджмент. 2015. № 1. С. 51-59.

11. Гудзенко Н.М., Коваль Н.І., Плахтій Т.Ф. Вплив інформаційних потреб користувачів на структуру та наповнення фінансової звітності. Економіка. Фінанси. Менеджмент: актуальні питання науки і практики. 2018. № 5. С.102-113.

12. Калетнік Г.М., Ціхановська В.М., Ціхановська О.М. Менеджмент та маркетинг: Навчальний посібник. К.: «Хай-Тек Прес». 2011.580 с.

13. Правдюк Н.Л. Обліково-аналітичне забезпечення управління маркетинговою ціновою політикою аграрного підприємства. Стан і перспективи розвитку обліково-інформаційної системи в Україні: матеріали V міжнар. наук.практ. конф., м. Тернопіль, 31 травня-01 червня 2018 р. Тернопіль: ТНЕУ, 2018. C.258-260.

14. Ліганенко I.В. Маркетингова стратегія в управлінні розвитком підприємства за умови стратегічних змін. Ефективна економіка. 2014. № 9. URL: http://www.economy.nayka.com.ua/?op=1\&z=3370.

15. Пальчук О.В., Савченко В.М., Тошина Н.М. Маркетинг і бухгалтерський облік маркетингової діяльності: Навчальний посібник. Кіровоград: Поліум, 2008. 228 с.

16. Економічна енциклопедія (у трьох томах). Том 2. за ред. С.В. Мочерного. К.: Видавничий центр «Академія», 2001. 848 с.

17. Положення Про документальне забезпечення записів в бухгалтерському обліку: Наказ Міністерства фінансів України від 24.05.1995 № 88. URL:https://zakon.rada.gov.ua (дата звернення: 28.02.2019).

18. Положення (стандарт) бухгалтерського обліку 16 «Витрати»: Наказ Міністерства фінансів України від 31.12.1999 № 318. URL: https://zakon.rada.gov.ua (дата звернення: 01.03.2019).

19. Про затвердження Плану рахунків бухгалтерського обліку та Інструкції про його застосування: наказ Міністерства фінансів України від 31.11.1999 № 291. URL: https://zakon.rada.gov.ua (дата звернення: 02.03.2019).

20. Національне положення (стандарт) бухгалтерського обліку 1 «Загальні вимоги до фінансової звітності»: наказ Міністерства фінансів України від 07.02.2013 № 73. URL:https://zakon.rada.gov.ua (дата звернення: 03.03.2019). 


\section{References}

1. Melnyk, D.P. (2006). Marketynhova stratehiia pidpryiemstva [Marketing strategy of the enterprise]. Visnyk Khmelnytskoho natsionalnoho universytetu - Herald of Khmelnytskyi national university, 3, 213-219 [in Ukrainian].

2. Semeniuk, S. (2015). Neobkhidnist rozroblennia marketynhovoi stratehii dlia pidpryiemstv [The need to develop a marketing strategy for enterprises]. Halytskyi ekonomichnyi visnyk - Herald of Galicia, 2 (49), 204-212 [in Ukrainian].

3. Savchuk, A.M. (2014). Skladovi informatsiinoho zabezpechennia stratehichnoho marketynhu pidpryiemstv torhivli [Components of information support of strategic marketing of trade enterprises]. Formuvannia rynkovykh vidnosyn v Ukraini - Market Relations Development in Ukraine, 207 (158), 66-71 [in Ukrainian].

4. Viter, S.A. \& Viter, Z.D. (2016). Oblikovo-analitychne zabezpechennia upravlinnia marketynhovymy vytratamy silskohospodarskykh pidpryiemstv [Accounting and analytical support for management of marketing expenses of agricultural enterprises]. Ahrosvit-Agrosvit, 12, 34-40 [in Ukrainian].

5. Derii, V.A. (2013). Vytraty na zbut u systemi obliku y analizu nevyrobnychykh vytrat [Costs of sales in the system of accounting and analysis of non-production costs]. Oblik $i$ finansy - Accounting and Finance, 4 (62), 20-23 [in Ukrainian].

6. Nazarova, K. \& Mysiuk, V. (2017). Oblik vytrat na marketynhovi komunikatsii pidpryiemstva [Cost accounting for marketing communications of the enterprise]. Visnyk KNTEU - Herald of KNUTE, 5, 129-140 [in Ukrainian].

7. Polishchuk, I.R. (2016). Upravlinnia vytratamy na zbut vidpovidno do marketynhovoi stratehii pidpryiemstva: statystychna otsinka ta oblikove zabezpechennia [Management of sales costs in accordance with the marketing strategy of the enterprise: statistical estimation and accounting support]. Hlobalni ta natsionalni problemy ekonomiky - Global and national problems of the economy, 9, 832-836 [in Ukrainian].

8. Lukan, O.M. (2015). Dokumentuvannia obliku vytrat marketynhovoi diialnosti [Documentation of accounting of expenses of marketing activity]. Naukovyi visnyk Chernivetskoho universytetu - Scientific herald of Chernivtsi University, 750, 125-129 [in Ukrainian].

9. Lukan, O.M. (2017). Oblik i analiz vytrat marketynhovoi diialnosti: avtoreferat dys. [Accounting and analysis of marketing activities]. Zhytomyr, 20 [in Ukrainian].

10. Bondarenko, V.M. (2015). Marketynhova stratehiia yak skladova stratehii rozvytku rehionu [Marketing strategy as part of the regional development strategy]. Ekonomika. Finansy. Menedzhment: aktualni pytannia nauky i praktyky - Economy. Finances. Management: topical issues of science and practice, 1, 51-59 [in Ukrainian].

11. Hudzenko, N.M., Koval N.I., \& Plakhtii, T.F. (2018). Vplyv informatsiinykh potreb korystuvachiv na strukturu ta popovnenia finansovoi zvitnosti [Influence of users' information needs on the structure and filling of financial statements]. Ekonomika. Finansy. Menedzhment: aktualni pytannia nauky i praktyky - Economy. Finances. Management: topical issues of science and practice, 5, 102-113 [in Ukrainian].

12. Kaletnik, H.M., Tsikhanovska, V.M., \& Tsikhanovska, O.M. (2011). Menedzhment ta marketynh: Navchalnyi posibnyk [Management and marketing: tutorial] Kyiv, Khai-Tek Pres [in Ukrainian].

13. Pravdiuk, N.L. (2018). Oblikovo-analitychne zabezpechennia upravlinnia marketynhovoiu tsinovoiu politykoiu ahrarnoho pidpryiemstva [Accounting and analytical support of management of marketing pricing policy of agrarian enterprise]. Proceedings 
from V Mizhnarodna naukova-praktychna konferentsia «Stan i perspektyvy rozvytku oblikovo-informatsiinoi systemy v Ukraini» - "The state and prospects of development of the accounting and information system in Ukraine», pp. 258-260, Ternopil: TNEU [in Ukrainian].

14. Lihanenko, I.V. (2014). Marketynhova stratehiia v upravlinni rozvytkom pidpryiemstva za umovy stratehichnykh zmin [Marketing strategy in managing the development of the enterprise subject to strategic changes]. Efektyvna ekonomika Effective economy, 9. Retrieved from http://www.economy.nayka.com.ua/ ?op=1\&z=3370 [in Ukrainian].

15. Palchuk, O.V., Savchenko, V.M. \& Toshyna, N.M. (2008). Marketynh i bukhhalterskyi oblik marketynhovoi diialnosti [Marketing and Marketing of Marketing Activities]. Kirovohrad, Polium, 228 [in Ukrainian].

16. Mochernyi, S.V. (2001). Ekonomichna entsyklopediia [Economic Encyclopedia]. Kyiv, Vydavnychyi tsentr «Akademiia», 848 [in Ukrainian].

17. Ministerstvo finansiv Ukrainy (1995). Polozhennia Pro dokumentalne zabezpechennia zapysiv $\mathrm{v}$ bukhhalterskomu obliku [Regulations on documentary accounting records]. Retrieved from https://zakon.rada.gov.ua [in Ukrainian].

18. Ministerstvo finansiv Ukrainy (1995). Polozhennia (standart) bukhhalterskoho obliku 16 «Vytraty» [Regulation (standard) of accounting 16 «Expenses»]. Retrieved from https://zakon.rada.gov.ua [in Ukrainian].

19. Ministerstvo finansiv Ukrainy (1999). Pro zatverdzhennia Planu rakhunkiv bukhhalterskoho obliku ta Instruktsii pro yoho zastosuvannia [On Approval of the Accountancy Account Plan and Instructions for its Application]. Retrieved from https://zakon.rada.gov.ua [in Ukrainian].

20. Ministerstvo finansiv Ukrainy (2013). Natsionalne polozhennia (standart) bukhhalterskoho obliku 1 «Zahalni vymohy do finansovoi zvitnosti» [National Accounting Standard (Standard) 1 «General Requirements for Financial Statements»]. Retrieved from https://zakon.rada.gov.ua [in Ukrainian].

\section{Відомості про автора}

ПРАВДЮК Наталія Леонідівна - доктор економічних наук, професор кафедри бухгалтерського обліку, Вінницький національний аграрний університет (21008, м. Вінниця, вул. Сонячна, 3, e-mail: npravduyk@gmail.com).

PRAVDIUK Nataliia - Doctor of Economic Sciences, Professor of Accounting Department, Vinnytsia National Agrarian University, (21008, 3 Sonyachna Str., Vinnytsia, e-mail: npravduyk@gmail.com).

ПРАВДЮК Наталия Леонидовна - доктор экономических наук, профессор кафедры бухгалтерского учёта, Винницкий национальный аграрный университет, (21008, г. Винница, ул. Солнечная, 3, e-mail: npravduyk@gmail.com).

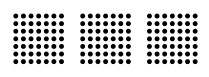

